\title{
A Contribution to the Critique of the Political Economy of Google
}

\author{
Christian Fuchs
}

\section{Introduction}

Google is the world's most accessed web platform: $46.0 \%$ of worldwide Internet users accessed Google in a three-month period (data source: alexa.com, http://internetworldstats.com/stats.htm; February 10, 2011). In January 2011, Google accounted for $65.6 \%$ of all searches in the US, Yahoo! for 16.1\%, Microsoft sites (including Bing, MSN, Windows Live) for 13.1\%, ask.com for 3.4\%, and AOL LLC for 1.7\% (http://www.comscore.com/Press_Events/ Press_Releases/2011/2/comScore_Releases_January_2011_U.S._Search_Engine_Rankings). In 2010, Google accounted on average for $85.07 \%$ of all worldwide searches, Yahoo for $6.12 \%$, Baidu for $3.33 \%$, Bing for $3.25 \%$, Ask for $0.67 \%$ and others for $1.56 \%$ January-December 2010, http://marketshare.hitslink.com/search-engine-marketshare.aspx?qprid=5). In China, Baidu accounted in 2010 for on average $60.4 \%$ of all searches and Google for only 37.7\% (January-December 2010, http://gs.statcounter.com/\#search_engine-CN-monthly-201001-201012).

Google has become ubiquitous in everyday life - it is shaping how we search, organize and perceive information in contexts like the workplace, private life, culture, politics, the household, shopping and consumption, entertainment, sports, etc. The phrase "to google" has even found its way into the vocabulary of some languages. The Oxford English Dictionary defines "to google" as "search for information about (someone or something) on the Internet, typically using the search engine Google" and remarks that the word's origin is "the proprietary name of a popular Internet search engine" (http:/ oxforddictionaries.com/view/entry/m_en_gb0342960\#m_en_gb0342960, accessed on February 10, 2011). The German Duden (2009 edition) defines the term "googeln" as "im Internet suchen" (p. $498,=$ to search on the Internet). The circumstance that a company name becomes part of a vocabulary indicates that the products of large monopoly capitalist companies have become so present in capitalist society that their existence is absolutely taken for granted, not questioned and so strongly fetishized that specific verbs ("to google", "googeln") are defined for expressing the usage of these products.

There are a lot of affirmative, uncritical popular science- and business studies- publications about Google that have a celebratory tone, take for granted economic power and do not see this kind of power's underbelly. For example, David Vise (2005) tells the Google Story in a celebratory tone. He argues that the great thing about Google is that it helps people "to find the information" (Vise 2005:292) they need and that it "reliably provides free information for everyone who seeks it" (Vise 2005:2). Tapscott and Williams invoke the images of revolution and participatory democracy when speaking about web 2.0 companies and therefore characterize Google as providing "participatory Web services" (Tapscott and Williams 2006:193). Bernard Girard (2009) says that Google has "democratized advertising" (Girard 2009:39) and "represents the invention of a new management model - and calling it revolutionary is no exaggeration" (Girard 2009:223). Jeff Jarvis says that talking about Google means "talking about a new society" that is built on "connections, links, transparency, openness, publicness, listening, trust, wisdom, generosity, efficiency, markets, niches, platforms, networks, speed, and abundance" (Jarvis 2009:240f). Books such as the Google Story (Vise 2005), What would Google do? (Jarvis 2009), The Google way (Girard 2009), or Googled (Auletta 2010) not only celebrate Google, but at the same time advance the individualistic myth of the American dream, in which hard working individuals have great ideas and thereby become successful. They ignore the 
role played by the work of employees and users in running a company like Google and the role of venture capital in financing it in the first instance.

Studying the implications of search engines has become a specific research field. Zimmer (2010) speaks therefore of the emergence of Web Search Studies as a subfield of Internet Studies. Within this research field, in contrast to popular science-celebrations, a number of critiques of Google has been advanced:

- Monopolization: Google holds a monopoly in the search engine market and contributes to the concentration of this market (Maurer, Balke, Kappe, Kulathuramaiyer, Weber and Zaka 2007; Van Couvering 2008, Van Hoboken 2009).

- Reality distortion: Google gives a distorted picture of reality that is incomplete, unsystematic and controls what is considered as existent and non-existent (Becker 2009, Darnton 2009, Lovink 2009, Stalder and Meyer 2009, Becker 2009). As users tend to be biased towards following the first search results, no matter if they are relevant for their search or not, Google tends to centralize attention to certain sites and to marginalize attention for other sites (Pan, Hembrooke, Joachims, Lorigo, Gay and Granka 2007).

- Surveillance: Google advances user surveillance and privacy violation (Aljifri and Navarro 2004; Andrejevic 2007:129-131; Halavais 2009, Hoofnagle 2009, Lobet-Maris 2009, Lovink 2009; Maurer, Balke, Kappe, Kulathuramaiyer, Weber and Zaka 2007; Munir and Yasin 2008, Rieder 2009, Stalder and Mayer 2009, Tatli 2008, Tavani 2005; Turow 2008:97; Vaidhyanathan 2011:chapter 3; Zimmer 2008a, b).

- Stratified attention economy: Powerful actors are more visible in Google search results than nonpowerful ones (Diaz 2008, Halavais 2009, Mayer 2009, Rieder 2009, Rogers 2009, Zook and Graham 2007) so that a Googlearchy (Hindman, Tsioutsiouliklis and Johnson 2003) or Googlocracy (Menczer, Fortunato, Flammini and Vespignani 2006) emerges. Introna and Nissenbaum (2000:181) argue that there is a tendency that Google gives "prominence to popular, wealthy and powerful sites at the expense of others" and that as a result the public character of the web is endangered.

- Intransparency: The PageRank algorithm is intransparent and kept secret (Lobet-Maris 2009). Google Scholar for example is a thorough search engine that produces better search results than some other academic search engines (Haya, Nygren and Widmark 2007) because it searches through the full text of academic papers, but its search process and coverage are kept secret (Jacsó 2005).

- Google advances ideology: Google's management style presents itself as decentralized, flat and based on self-organization, just like the operations of the search engine, which ideologically hides that Google is a force of centralization (Jakobsson and Stiernstedt 2010a). Google advances the techno-determinist ideology that information technology will solve society's problems (Vaidhyanathan 2011:chapter 2).

- Google is of public interest, but has a private character: For example, Google Books is an Americancentred project that does not make digital books available to the public, but operates the digitizing of books as private business (Baksik 2006, Jeanneney 2007, Vaidhyanathan 2011:chapter 5). Also Google Maps and Google Earth are primarily directed towards advertising businesses (Lee 2010a).

- Censorship: From 2005 until 2010, Google allowed for business purposes the censorship of search results for keywords like Tiananmen Square, freedom of speech Tibet or Taiwan in China, which some see as a contribution to civil rights violation (Halavais 2009; Hinman 2005, Jiang and Chang 2008, Vaidhyanathan 2011:chapter 4, Zook and Graham 2007). Others argue that the critique of Chinese censorship of the Internet ignores Western problems of the Internet, such as its domination by commercial and entertainment value (Lee 2010b).

- Political dominance: The global nature of Google's services allows the company to evade and bypass national regulations (Kumar 2010, Munir and Yasin 2008).

- Digital divide: There is a divide in the skills needed for informed searches (Halavais 2009).

- Human capacities: Google is reducing humans' capacities of creative and thoughtful reflection (Carr 2008), reading and writing (Weber 2009).

The task of this paper is to critically analyze the political economy of Google. The approach of the political economy of the media and communication analyzes "the production, distribution, and consumption of resources, including communication resources" (Mosco 2009:2). In a capitalist society, i.e. a society based on the accumulation of capital, "the commodity-form of the product of labour, or the value-form of the commodity, is the economic cellform” (Marx 1867:90). A commodity is a good that is exchanged in a certain quantity for a certain quantity of money 
(or another generalized medium of exchange): $\mathrm{x}$ commodity $\mathrm{A}=\mathrm{y}$ commodity $\mathrm{B}$. As capitalism is an "immense collection of commodities" (Marx 1867:125), the analysis of the political economy of capitalism should begin with "the analysis of the commodity" (Marx 1867: 125). Google is a profit-oriented company, therefore analyzing how Google's commodity production, distribution and consumption process works is of central importance. In the existing research literature, no theoretically grounded systematic analysis of Google's capital accumulation process has been provided so far. This paper wants to contribute to filling this gap. Related to this analysis is the normative question about the good and bad sides of Google, if it is "evil" or not. Google itself claims that it is not "evil". The approach of Critical Political Economy does "not preach morality at all” (Marx and Engels 1846:264), but wants to understand and change conditions that humans live and act in and by which their thinking and actions are shaped. Critical theorists "do not put to people the moral demand: love one another, do not be egoists, etc.; on the contrary, they are very well aware that egoism, just as much selflessness, is in definite circumstances a necessary form of the self-assertion of individuals“ (Marx and Engels 1846:264). This means that a critical analysis of Google goes beyond moral condemnation or moral celebration, but rather tries to understand the conditions and contradictions that shape the existence of Google and its users. This work therefore also wants to make a contribution to contextualizing normative questions about Google in the political economy of contemporary society.

In section 2, basic economic data about Google are outlined and Google's cycle of capital accumulation is explained. In section 3, the role of user surveillance in Google's capital accumulation cycle is outlined and a critical interpretation of the role of advertising in Google's terms of service and privacy policies is given. Finally, it is discussed in the conclusion if Google is "evil".

\section{Google's Political Economy}

Google, which was founded in 1998 by Larry Page and Sergey Brin, was transformed into a public company on August 19, 2004 (Vise 2005:4). Google acquired the video sharing platform YouTube for US\$1.65 billion in 2006 and the online advertising service company DoubleClick for US\$3.1 billion in 2008 (Stross 2008:2).

In 2010, Google was after IBM, Microsoft and Oracle the fourth largest software company in the world (Forbes Global 2000, 2010 list). In the list of the world's largest companies, Google has rapidly increased its ranking (table 1). 2010 has been a record profitable year for Google: its profits were US\$8.5 billion (Google SEC Filings, Annual Report 2010), the largest amount since the company's creation in 1998. Since 2004, Google's annual profits rapidly increased (see figure 1).

Table 1. Google's ranking in the list of the largest public companies in the world (data source: Forbes Global 2000, various years; the ranking is based on a composite index of profits, sales, assets and market value)

\begin{tabular}{|l|l|l|l|l|l|l|}
\hline 2004 & 2005 & 2006 & 2007 & 2008 & 2009 & 2010 \\
\hline 904 & 439 & 289 & 213 & 155 & 120 & 120 \\
\hline
\end{tabular}

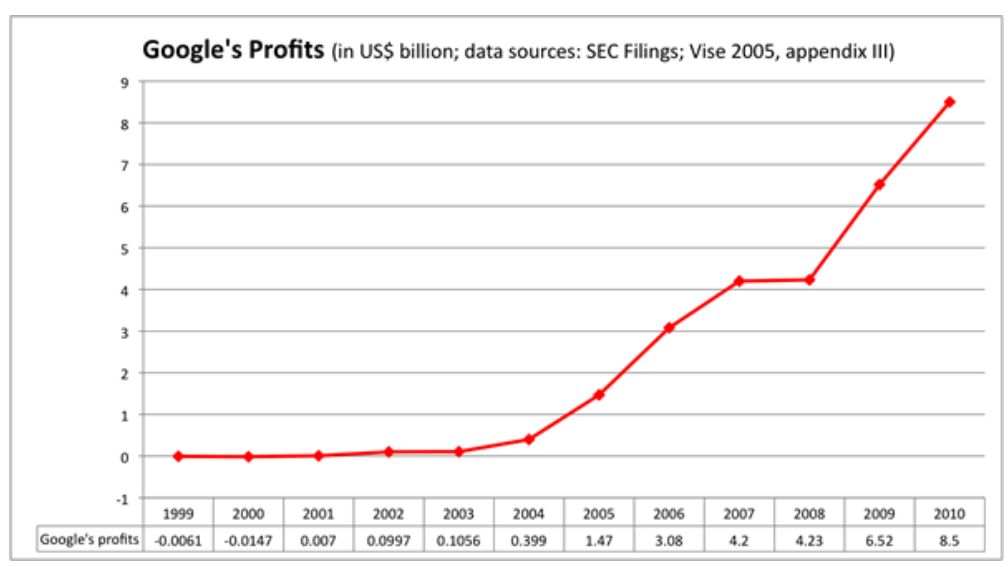

Figure 1. The development of Google's profits 
In 2008, the year that a new world economic crisis hit capitalism, Google's market value dropped from \$US147.66 billion (2007) to \$US106.69 billion (data source: Forbes Global 2000, lists for the years 2007 and 2008). Google's profits remained constant in this period of world economic crisis (2007: \$US 4.2 billion, 2008: \$US 4.23 billion, Forbes Global 2000, lists for the years 2007 and 2008). In 2009, Google's market value increased to \$US 169.38 billion (data source: Forbes Global 2000, year 2009). Google’s profits reached a new all-time high of \$US 6.52 billion in 2009 and skyrocketed to \$US 8.5 billion in 2010 (data source: Google SEC Filings, annual reports various years). So Google's profits were not harmed by the economic crisis that started in 2008. The company stabilized its profits in 2008 in comparison to 2007, accounted for a 65\% growth of its profits in 2009 and a 76.7\% growth in 2010. An economic crisis results in the shrinking of the profits of many companies, which can have negative influences on advertising markets because companies with declining profits have less money to spend for marketing purposes. As a result, the financial years 2008 and 2009 brought about declining profits for many advertising-financed media companies (Fuchs 2011, chapter 6). Google may have benefited from the crisis because in crisis times "advertisers are more concerned about the costs and direct results of their advertising campaigns" and Google offers good ways of "controlling and measuring [...] campaign's effectiveness" (Girard 2009:215). In non-marketing research language this means that Google provides a form of advertising that is based on the close surveillance of users. Google advertising clients know a lot about who clicks when on their ads. Surveillance makes Google advertising predictable, capitalist companies seek to control unpredictability of investments especially in times of crisis and therefore welcome Google advertisement because it is based on a form of economic user surveillance.

Ken Auletta (2010:19) in his celebratory book Googled claims that Google is an egalitarian company and that Brin, Page and Schmidt have modest salaries. Can one speak of economic modesty, if four persons control more than $70 \%$ of the voting power and more than $90 \%$ of the common stock? Page, Brin and Schmidt increased their personal wealth by a factor of 4 in the years 2004-2010 (figure 2). They are among the richest Americans. It is not that Google is more or less "evil" than any other capitalist company (table 2). Google is an ordinary capitalist company that accumulates profit and thereby also personal wealth of a few by exploiting the many.

Table 2. Development of the ranking of Google's 3 richest directors in the list of the 300 richest Americans (data source: Forbes 400 List of the Richest Americans)

\begin{tabular}{|l|l|l|l|l|l|l|l|}
\hline & 2004 & 2005 & 2006 & 2007 & 2008 & 2009 & 2010 \\
\hline Larry Page & 43 & 16 & 13 & 5 & 14 & 11 & 11 \\
\hline Sergey Brin & 43 & 16 & 12 & 5 & 13 & 11 & 11 \\
\hline Eric Schmidt & 165 & 52 & 51 & 48 & 59 & 40 & 48 \\
\hline
\end{tabular}

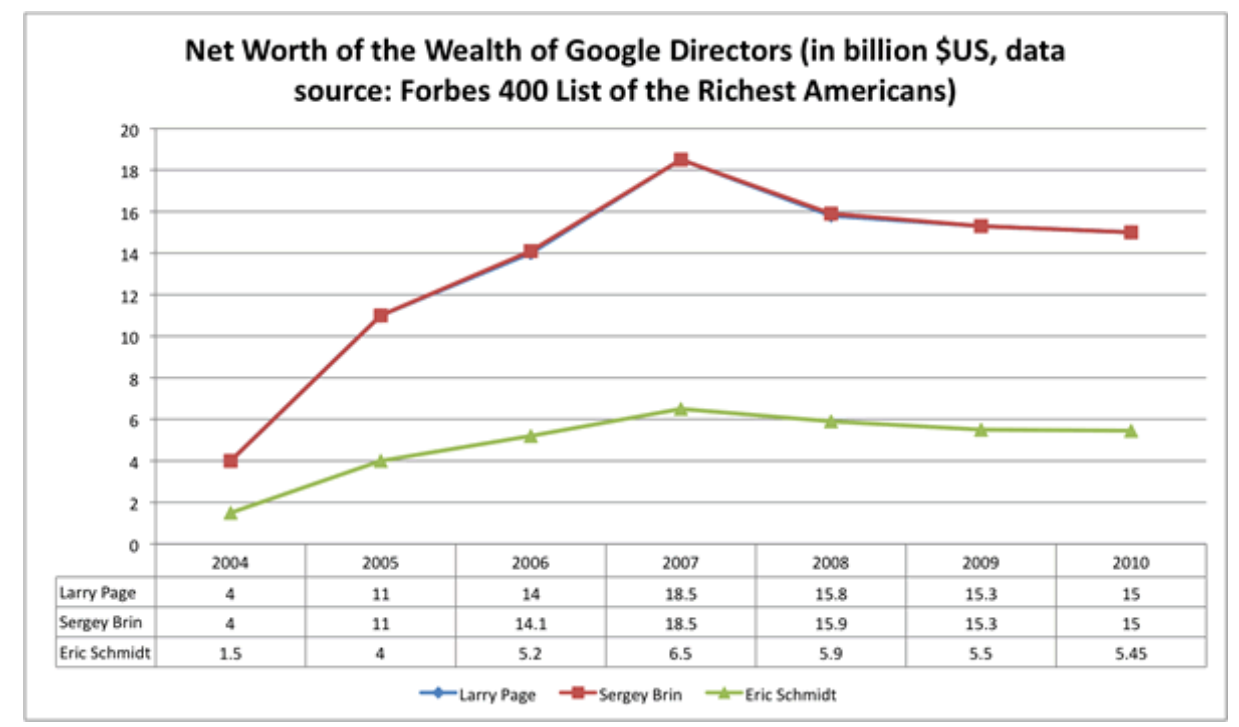

Figure 2. Development of the wealth of Google's 3 richest directors 
In 2010, four members of Google's board of directors (Larry Page, Sergey Brin, Eric Schmidt and L. John Doerr) owned $93.2 \%$ of Google's class B common stock and controlled $70.1 \%$ of the total voting power (see table 3). In comparison, Google's 20000 employees have almost no ownership and voting power share (the share of stock options and voting power can only be small if more than $90 \%$ respectively $70 \%$ is owned/controlled by a power elite consisting of four persons) and Google's 900 million users have no ownership and voting power share. Google's users and employees produce its surplus value and have made it into the powerful company that it is today. Using Google or working for Google means being permanently exploited and dispossessed of the profit that is being created by the users and employees. The contemporary proletariat does not so much work at conveyor belts in industrial firms, it to a certain degree creates surplus value for Google (and other social media companies) by using and producing its services.

Table 3. Stock ownership shares and voting power shares at Google, 2010, data sources: Google financial data: Google Proxy Statement 2010 (http://investor.google.com/documents/2010_google_proxy_statement.html), worldwide Internet users: internetworldstats.com, accessed Feb 10, 2011; share of Google users in worldwide Internet users: alexa.com, top sites, accessed Feb 10, 2011)

\begin{tabular}{|l|l|l|l|}
\hline Name & Role & $\begin{array}{l}\text { Ownership share of Google's } \\
\text { class B common stock }\end{array}$ & Share of total voting power \\
\hline Larry Page & Director, Founder & $39.3 \%$ & $29.6 \%$ \\
\hline Sergey Brin & Director, Founder & $38.6 \%$ & $29.0 \%$ \\
\hline Eric Schmidt & CEO & $12.7 \%$ & $9.5 \%$ \\
\hline L. John Doerr & Director & $2.6 \%$ & $2.0 \%$ \\
\hline $\begin{array}{l}19835 \text { employees } \\
\text { (December 2009) }\end{array}$ & Surplus value production & & \\
\hline $\begin{array}{l}\text { 900 million users } \\
\text { (February 2011) }\end{array}$ & Surplus value production & & \\
\hline Total & & $93.2 \%$ & \\
\hline
\end{tabular}

These data show that Google is one of the most profitable media companies in the world. But how exactly does it achieve this profit? How does it accumulate capital? Answering this question, requires a political economy analysis of Google's capital accumulation cycle.

There are already some existing analyses of Google that stand in the political economy tradition. I agree with Matteo Pasquinelli $(2009,2010)$ that an analysis and critique of the political economy of Google and other web 2.0 platforms is needed. I do however not agree with his form of analyzing the political economy of Google by employing the Marxian concept of rent. Pasquinelli's ideas are based on the autonomist Marxist approach. He argues that Google creates and accumulates value by its page rank algorithm. He says that Google's profit is a form of cognitive rent. Marx (1867) showed that technology never creates value, but is only a tool that is used by living human labour for creating labour. Therefore Pasquinelli advances a technological-deterministic assumption that the page rank algorithm creates value. Marx (1894) argued that rent is exchanged for land.

Marx (1894, chapter 48) formulated the trinity formula that expresses the three aspects of the value of a commodity: profit (including interest), rent, wages. Profit is attached to capital, rent to land, and wage labour to labour. The three kinds of revenue are connected to the selling of labour power, land, and goods. Rent is obtained by lending land or real estates. It is not the direct result of surplus value production and human labour. No new product is created in the renting process. Rent indirectly stems from surplus value because capitalists take part of the surplus in order to rent houses, but it is created in a secondary process, in which surplus value is used for buying real estates. "First we have the use-value land, which has no value, and the exchange-value rent" (Marx 1894:956). "Value is labour. So surplus-value cannot be earth" (Marx 1894:954). Therefore using the category of rent for describing Internet practices and their outcomes means to assume that activities on the corporate Internet, such as surfing on Google or creating content on You'Tube or Facebook, are not exploitative. The category of cognitive rent is not useful for a critical political economy of the Internet and web 2.0, the notion of the Internet prosumer commodity that is created by exploited knowledge labour, as the following analysis will show, is more feasible. 
Hyunjin Kang (2009) argues that Google commodifies its users, identifies the actors in this commodification process and compares them to the traditional mass media advertising process. Bermejo (2009) says that Google does not commodity the attention time of users, but keywords that are sold in biddings to advertisers. Halavais (2009:82) and Petersen (2008) argue that Google and other web 2.0 platforms are based on the exploitation of free user labour. Jakobsson and Stiernstedt (2010b) argue that Google "is engaged in an accumulation by dispossession of one of the fundamental characteristics of being human: the ability to communicate through symbols, signs, and other means of representation". Wasko and Erickson (2009:383) say that "YouTube is not shy about helping advertisers exploit users to generate revenue". Vaidhyanathan (2011:3) stresses that users are "not Google's customers: we are its product. We $[\ldots]$ are what Google sells to advertisers". Lee (2011) argues that Google sells three types of commodities: keywords, keyword statistics and search results.

Such analyses are important contributions to the political economy of the Internet-debate, but do not specify the details of Google's capital accumulation cycle, which requires grounding in Marx's theory.

Alvin Toffler (1980) introduced the notion of the prosumer in the early 1980s. It means the "progressive blurring of the line that separates producer from consumer" (Toffler 1980:267). Toffler describes the age of prosumption as the arrival of a new form of economic and political democracy, self-determined work, labour autonomy, local production, and autonomous self-production. But he overlooks that prosumption is used for outsourcing work to users and consumers, who work without payment. Thereby corporations reduce their investment costs and labour costs, jobs are destroyed, and consumers who work for free are extremely exploited. They produce surplus value that is appropriated and turned into profit by corporations without paying wages. Notwithstanding Toffler's uncritical optimism, his notion of the "prosumer" describes important changes of media structures and practices and can therefore also be adopted for critical studies.

Dallas Smythe (1981/2006) suggests that in the case of media advertisement models, the audience is sold as a commodity to advertisers: "Because audience power is produced, sold, purchased and consumed, it commands a price and is a commodity. [...] You audience members contribute your unpaid work time and in exchange you receive the program material and the explicit advertisements" (Smythe 1981/2006:233, 238). With the rise of usergenerated content, free access social networking platforms, and other free access platforms that yield profit by online advertisement - a development subsumed under categories such as web 2.0, social software, social media and social networking sites - the web seems to come close to accumulation strategies employed by the capital on traditional mass media like TV or radio. The users who google, upload photos, and images, write wall posting and comments, send mail to their contacts, accumulate friends or browse other profiles on Facebook, constitute an audience commodity that is sold to advertisers. The difference between the audience commodity on traditional mass media and on the Internet is that, in the latter case, the users are also content producers; there is user-generated content, the users engage in permanent creative activity, communication, community building, and content-production. That the users are more active on the Internet than in the reception of TV or radio content, is due to the decentralized structure of the Internet, which allows many-to-many communication. Due to the permanent activity of the recipients and their status as prosumers, we can say that in the case of Facebook and the Internet the audience commodity is an Internet prosumer commodity (Fuchs 2010a).

Google relates to Internet prosumer commodification in two ways: On the one hand it indexes user-generated content that is uploaded to the web and thereby acts as a meta-exploiter of all user-generated content producers. Without user-generated content by unpaid users, Google could not perform keyword searches. Therefore Google exploits all users, who create World Wide Web (WWW) content. On the other hand users employ Google services and thereby conduct unpaid productive surplus-value generating labour. Such labour includes for example: searching for a keyword on Google, sending an e-mail via GMail, uploading or searching for a video on YouTube, searching for a book on Google Print, looking for a location on Google Maps or Google Earths, creating a document on GoogleDocs, maintaining or reading a blog on Blogger/Blogspot, uploading images to Picassa, translating a sentence with Google Translate, etc. Google generates and stores data about the usage of these services in order to enable targeted advertising. It sells these data to advertising clients, who then provide advertisements that are targeted to the activities, searches, contents and interests of the users of Google services. Google engages in the economic surveillance of user data and user activities, thereby commodifies and infinitely exploits users and sells users and their data as Internet prosumer commodity to advertising clients in order to generate money profit. Google is the ultimate economic surveillance machine and the ultimate user-exploitation machine. It instrumentalizes all users and all of their data for creating profit.

Google users are double objects of commodification: 1) they and their data are Internet prosumer commodities 
themselves, 2) through this commodification their consciousness becomes, while online, permanently exposed to commodity logic in the form of advertisements. Most online time is advertising time served by Google or other online advertising companies.
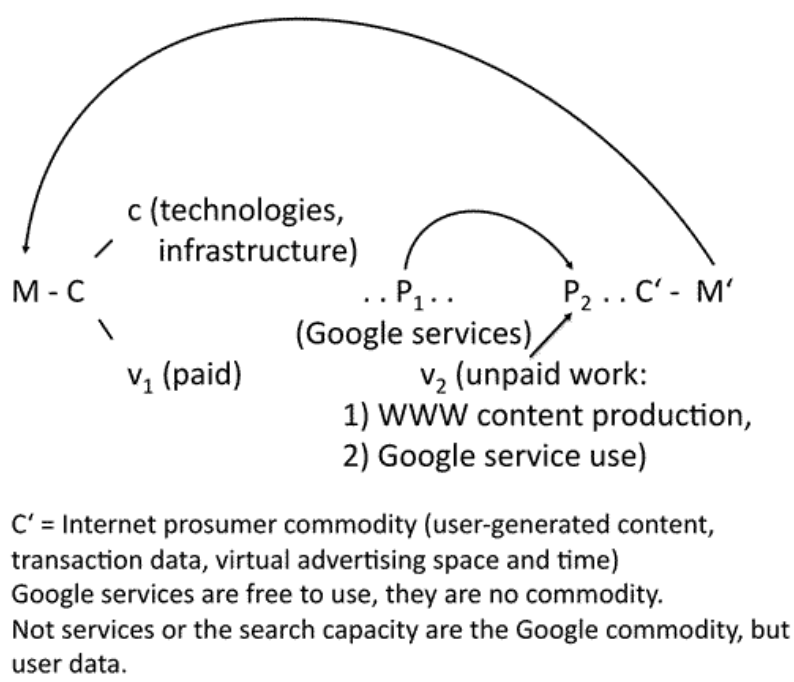

Figure 2. Development of the wealth of Google's 3 richest directors

Figure 3 shows the process of capital accumulation on Google. Google invests money (M) for buying capital: technologies (server space, computers, organizational infrastructure, etc) and labour power (paid Google employees). These are the constant and variable capital outlays. The Google employees make use of the fixed capital in order to produce (P1) Google services (like Google Search, YouTube, GMail). Google services are no commodities, they are not sold to users, but rather provided to users without payment. Free access provision and a large number of services allow Google to attract many users and to collect a lot of data about their searches. The Google search, Google's core service, is powered by the unpaid work of all those, who create web pages and web content that are indexed by Google. They are unpaid by Google, although Google uses their content for making money. The Google services and the unpaid labour of web content creators is the combined foundation for the exploitation of the Google users. They engage in different unpaid work activities (searching, e-mailing, creating documents, blogging, reading blogs, uploading videos or images, watching videos or images, etc) (P2). Thereby a new commodity C' is created, the Google prosumer commodity. It is created by the unpaid work of Google users and WWW content creators and consists of a multitude of data about user interests and activities. Google exploits Google users and WWW content producers because their work that serves Google's capital accumulation is fully unpaid. Google in processes of economic surveillance collects a multitude of data about usage behaviour and users' interests. The Google prosumer commodity C' is sold to advertising clients (the process $\left.C^{\prime}-\mathrm{M}^{\prime}\right)$ : Google attains money (M') from advertising clients, who in return can use the data of the Google prosumer commodity they have purchased in order to present targeted advertisements to Google users. Google thereby increases its invested money M by a profit p: M' $=\mathrm{M}+\mathrm{p} \cdot \mathrm{p}$ is partly reinvested and partly paid as dividend to Google stockowners.

For Marx (1867), the profit rate is the relation of profit to investment costs: $\mathrm{p}=\mathrm{s} /(\mathrm{c}+\mathrm{v})=$ surplus value / (constant capital (= fixed costs) + variable capital (= wages)). If Internet users become productive web 2.0 prosumers, then in terms of Marxian class theory this means that they become productive labourers, who produce surplus value and are exploited by capital because for Marx productive labour generates surplus value (Fuchs 2010a). Therefore not merely those who are employed by Internet corporations like Google for programming, updating, and maintaining the soft- and hardware, performing marketing activities, etc., are exploited surplus value producers, but also the users and prosumers, who engage in the production of user-generated content and data (like search queries on Google). Google does not pay the users for the production of content and transaction data. Google's accumulation strategy is to give them free access to services and platforms, let them produce content and data, and to accumulate a large 
number of prosumers that are sold as a commodity to third-party advertisers. Not a product is sold to the users, but the users and their data are sold as a commodity to advertisers. Google's services are not commodities. They are free of charge. The commodity that Google sells is not Google services (like its search engine), but the users and their data. The golden rule of the capitalist Internet economy is that the more users a platform has, the higher the advertising rates can be set. The productive labour time that is exploited by Google on the one hand involves the labour time of the paid employees and on the other hand all of the time that is spent online at Google services by the users. For the first type of knowledge labour, Google pays salaries. The second type of knowledge is produced completely for free (without payment). There are neither variable nor constant investment costs. The formula for the profit rate needs to be transformed for this accumulation strategy:

$$
\begin{aligned}
& \mathrm{p}=\mathrm{s} /(\mathrm{c}+\mathrm{v} 1+\mathrm{v} 2) \\
& \mathrm{s} \text { : surplus value, } \mathrm{c} \text { : constant capital, } \mathrm{v} 1 \text { : wages paid to fixed employees, } \mathrm{v} 2 \text { : wages paid to users }
\end{aligned}
$$

The typical situation is that $\mathrm{v} 2=>0$ and that $\mathrm{v} 2$ substitutes $\mathrm{v} 1(\mathrm{v} 1=>\mathrm{v} 2=0)$. If the production of content (web content that is indexed by Google) and data (search keywords, data generated by the use of Google services) and the time spent online were carried out by paid employees, Google's variable costs would rise and profits would therefore decrease. This shows that prosumer activity in a capitalist society can be interpreted as the outsourcing of productive labour to users, who work completely for free and help maximizing the rate of exploitation $(\mathrm{e}=\mathrm{s} /$ $\mathrm{v}=$ surplus value / variable capital) so that profits can be raised and new media capital may be accumulated. This situation is one of infinite exploitation of the users. Capitalist prosumption is an extreme form of exploitation, in which the prosumers work completely for free. Google infinitely exploits its users and the producers of web content that is indexed on Google.

That surplus value generating labour is an emergent property of capitalist production, means that production and accumulation will break down if this labour is withdrawn. It is an essential part of the capitalist production process. That prosumers conduct surplus-generating labour, can also be seen by imagining what would happen if they would stop using Google: The number of users would drop, advertisers would stop investments because no objects for their advertising messages and therefore no potential customers for their products could be found, the profits of Google would drop, and the company would go bankrupt. If such activities were carried out on a large scale, a new economy crisis would arise. This thought experiment shows that users are essential for generating profit in the new media economy. Furthermore they produce and co-produce parts of the products, and therefore parts of the use value, exchange value, and surplus value that are objectified in these products.

Googleplex, which is located in Mountain View, California, includes services for child care, personal trainers, haircutters, bike repair, car wash, oil change as well as a laundry, restaurants, cafeterias, bars, sports halls, gyms, swimming halls, volleyball courts, (Stross 2008:13). Google adopted a work time regulation introduced by the 3M company: A certain share of the work time of the employees can be used for self-defined projects. Google has adopted the $20 \%$ rule: 'We offer our engineers '20-percent time' so that they're free to work on what they're really passionate about. Google Suggest, AdSense for Content, and Orkut are among the many products of this perk" (http://www.google.com/jobs/lifeatgoogle/englife/index.html). This statement is a contradiction in terms: on the one hand Google says that its employees are "free to work on what they're passionate about", on the other hand the company seems to expect that the outcome of this work should be new services owned and operated and thereby monetized by Google. Would Google also grant its employees work time for engaging in building an anti-capitalist new media union or for writing and publishing an anti-Google manifesto? There seems to be "a lot of internal pressure to demonstrate progress with their personal projects, and employees that show little progress are seen as perhaps not being up to the Google standard" (Girard 2009:67).

Gilles Deleuze (1995) has described the emergence of a society of control, in which individuals discipline themselves. He compared the individual in disciplinary society to a mole and the individual in the society of control to a serpent. The mole as a symbol of disciplinary society is faceless and dumb and monotonously digs his burrows; the snake is flexible and pluralistic. The Google worker is a serpent: $s /$ he flexibly switches between different activities (leisure, work) so that the distinction between leisure and work, play and labour, collapses. Being employed by Google means having to engage in Google labour life and Google play life, Google employees are exploited playbourers. At Google, it becomes difficult to distinguish play and work. Luc Boltanski and Éve Chiapello (2006) argue that the rise of participatory management means the emergence of a new spirit of capitalism that subsumes values of the 
political revolt of 1968 and the subsequently emerging New Left such as autonomy, spontaneity, mobility, creativity, networking, visions, openness, plurality, informality, authenticity, emancipation, and so on, under capital. The topics of the movement would now be put into the service of those forces that it wanted to destroy. Google's management strategy is on the one hand based on the expectation that an integration of work time and free time in one space and the creation of happiness and fun inside the company make Google employees work longer and more efficiently. It aims at what Marx (1867:chapter 16) termed a) absolute surplus value production and b) relative surplus value production: the production of more surplus value by a) increasing the total labour time, b) increasing the efficiency (output per unit of time) of production. On the other hand it assumes that a relative freedom of action (the $20 \%$ policy) can generate new technologies that can be monetized and that this policy makes the workers happy so that they work more efficiently.

Surveillance of user data is an important part of Google's operations. It is, however, subsumed under Google's political economy, i.e. Google engages in user surveillance for the end of capital accumulation. Google surveillance is therefore a form of economic surveillance. Next, Google's surveillance of user will be further analyzed.

\section{Google's Capital Accumulation Model and Surveillance}

Using Google Street View, one does not get an impression of how the two largest buildings of Googleplex, buildings number 40 and 43 that are connected to each other, because Google Drive and the small roads next to the two buildings are not part of Street View and the pictures of building number 43 that should be accessible by going to the small street next to building number 43 are blurred (data source: Google Street View, accessed on February 10, 2011, 19:40 CET). Also one does not get a view of other Google buildings, either because roads are not visually accessible or the buildings are hidden by trees (for example all buildings of the Google West Campus, buildings 45, 46, 47, 1055, 1098, 900, 1600, Plymouth 1, Plymouth 2). Facing the criticism that photographing citizens' private housing is a violation of privacy, Google's CEO Eric Schmidt commented: "So, you can just move, right?" (http:// www.marketwatch.com/story/wary-of-google-street-view-move-ceo-says-2010-10-22). These circumstances reveal the class-divided action of Google: digitizing the world's information includes taking pictures of ordinary citizens' houses, whereas the visual structure of Google's own headquarters remains hidden. Google treats itself with a different logic than it treats citizens. It engages in the surveillance of citizens, but not in the surveillance of Google.

Anderson (2009:chapter 8) argues that Google is a citadel of the "freeconomy" that is based on the principle of giving something for free (access to Google services) in order to sell something else for making profit (advertising). "Companies like Google simply track people's everyday behavior online and distill valuable intelligence from the patterns the behavior reveals. No one minds because the resulting products like search results, are useful" (Carr 2009:138f). Do the users really not mind about Google surveillance or do they just not know enough about it? There was a lot of public criticism of Google's surveillance practices (like in the case of Google StreetView), so one cannot say that nobody minds. Anderson (2009:223) says that the online freeconomy does not mean less privacy because "most ad-driven sites have privacy policies" and the young generation does not value privacy anyhow. "After you've 'overshared' pictures of the drunken scene at your last frat party and described the ups and downs of your latest love affair, how much worse is it if a marketer sends you a discount on a clothing line based on your listed preferences?" (Anderson 2009:223). The sharing of pictures is not an economic issue, whereas the use of user data for online advertising is. The crucial thing about Google's advertising strategy is that it commodifies user data and thereby exploits them economically. Sharing pictures is not an economic action, whereas Google advertising is a problematic economic action - it is exploitation. Anderson's comparison of non-economic and economic processes is misleading.

Google's Eric Schmidt dreams of storing "all of your information" so that "we would know enough about you to give you targeted information, the targeted news, the targeted advertising, to make instantaneous, and seamless, happen". He calls this "transparent personalization" (http://www.google.com/press/podium/ana.html). Google co-founder Sergey Brin suggested a Google Artificial Intelligence dimension, in which brains are "augmented by Google. For example you think about something and your cell phone could whisper the answer into your ear" (Sergey Brin, cited in: Carr 2009:213). Brin: "Perhaps in the future, we can attach a little version of Google that you just plug into your brain” (Sergey Brin, cited in: Vise 2005:292). Google wired with all human brains would be the ultimate form of constant biopolitical exploitation - all human thoughts could be directly transformed into commodities that are sold as data to advertising clients. A perfect dynamic profile of each individual could be created so that not 
only his/her general interests are targeted by advertisements, but also commodity advertisements could be served in the second one thinks about a certain circumstance. Targeted advertisements could be directly and continuously be transported to human brains. Google's vision of Artificial Intelligence is constant real time biopolitical exploitation. Hardt and Negri have based on Foucault argued that contemporary capitalism is based on a form of biopower. "Biopower thus refers to a situation in which what is directly at stake in power is the production and reproduction of life itself" (Hardt and Negri 2000:24). Google on the one hand aims at commodifying all knowledge on the Internet and to erect a panopticon that surveils all online user activities. It aims at the commodification of user's knowledge, which is an aspect of human subjectivity. On the other hand Google dreams of the vision that its surveillance reaches directly into the brains of humans in order to monitor all human thoughts. In Google's vision, thinking should be exploited and commodified continuously in real time. Google's vision is one of total surveillance, exploitation and commodification of all human thoughts and activities.

Google uses a powerful search algorithm. The details of the PageRank algorithm are secret. Basically small automated programmes (web spiders) search the WWW, the algorithm analyzes all found pages, counts the number of links to each page, identifies keywords for each page and ranks its importance. The results can be used for free via the easy user interface that Google provides. Google develops ever-newer services that are again offered for free. The PageRank algorithm is a form of surveillance that searches, assesses and indexes the WWW. Google does not pay for the circumstance that it uses web content as resource, although results are provided to users when they search for keywords so that data about user interests are generated that are sold to advertising clients. Google benefits monetarily from the expansion of the web and user-generated content. The more websites and content there are on the WWW, the more content and pages Google can index in order to provide search results. The more and the better search results there are, the more likely users are to use Google and to be confronted with advertisements that match their searches, on which they might click.

The more users of Google's services there are, the more data about the services' users is stored and assessed. Google sells advertisements that match search keywords to ad clients that bid for advertising positions (Google AdWords). There are auctions for ad space connected to certain keywords and screen locations. Google sets the minimum bids. Ads that are clicked more frequently are displayed at a better position on the Google result pages (Girard 2009:31). Specific advertisements are presented to users, who conduct searches containing specific keywords. Google AdSense enables website operators to include Google adverts on their websites and to achieve revenue for each click on an advertisement. Google shares parts of the ad revenue with the website operators that participate in the AdSense programme. Advertisements can be presented in a targeted way to specific groups of users. For doing so, Google collects a lot of information about users. It engages in user surveillance. It is important to study what kind of data about users Google collects, monitors and commodifies.

Stalder and Mayer (2009) say that Google stores data about users as knowledge persons, social persons and physical persons. Zimmer (2008b) argues that Google collects general, academic, political, social, personal, financial, consumer and technological information about users. It is important to classify Google's surveillance data, but a good typology is not an arbitrary list of categories, but is rather based on theoretically grounded criteria that logically explain the existence of categories.

Information can be conceived as a threefold process of cognition, communication and co-operation (Fuchs 2008, 2010b). Cognition is a process that organizes subjective systemic knowledge. A cognizing individual can connect him- or herself to another person by using certain mediating systems. When it comes to feedback, the persons enter an objective mutual relationship, i.e., communication with the help of symbolic systems that help in establishing shared meanings of certain aspects of reality. Communicating knowledge from one system to another causes structural changes in the receiving system. From communication processes shared or jointly produced resources can emerge, i.e., co-operation. Knowledge is in this concept seen as a dynamic, relational social process. The triad can also be seen as one of the individual, social relations, and social systems. This corresponds to the three steps of development in Hegelian dialectics (being-in-itself/identity, being-for-another, being-in-and-for-itself) and to Peirce's triad of firstness, secondness, and thirdness. Google surveillance is based on the collection, storage, assessment and commodification of data about users' cognition, communication, and co-operation (see table 4).

Society can be conceived as consisting of interconnected subsystems that are not independent and based on one specific function they fulfil, but are open, communicatively interconnected, and networked. As subsystems of a model of society one can conceive the ecological system, the technological system, the economic system, the political system, and the cultural system (Fuchs 2008, Fuchs 2010c, figure 4). Why exactly these systems? In order to survive, humans in society have to appropriate and change nature (ecology) with the help of technologies so that they can 
produce resources that they distribute and consume (economy), which enables them to make collective decisions (polity), form values, and acquire skills (culture). The core of this model consists of three systems (economy, polity, culture). This distinction can also be found in other contemporary sociological theories: Giddens (1984:8-34) distinguishes between economic institutions, political institutions, and symbolic orders/modes of discourse as the three types of institutions in society. Bourdieu (1986) speaks of economic, political, and cultural capital as the three types of structures in society. Jürgen Habermas (1981) differs between the lifeworld, the economic system, and the political system.

Each of these three systems is shaped by human actors and social structures that are produced by the actors and condition the actors' practices. Each subsystem is defined and permanently re-created by a reflexive loop that productively interconnects human actors and their practices with social structures.

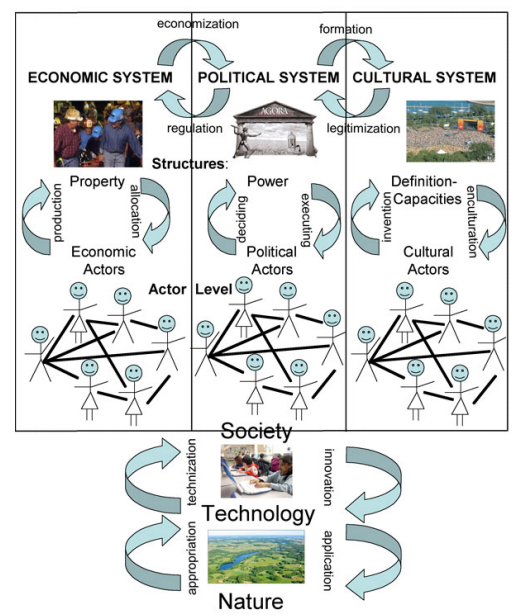

Figure 4. Society as dynamic, dialectical system

The economic system can only produce goods that satisfy human needs by human labour power that makes use of productive and communication technologies in order to establish social relations and change the state of natural resources. The latter are transformed into economic goods by the application of technologies to nature and society in labour processes. The economy is based on the dialectic of natural resources and labour that is mediated by technology. We can therefore argue that socially transformed nature and technology are aspects of the economic system. In all of these systems, users act as individuals and social beings. As individuals, they have a personality that is characterized by specific qualities.

The economic base is constituted by the interplay of labour, technology, and nature (ecology) so that economic goods are produced that satisfy human needs. The superstructure is made up by the interconnection of the political and the cultural system, so that immaterial goods emerge that allow the definition of collective decisions and societal value structures. The superstructure is not a mechanic reflection, that is, a linear mapping, of the base, that is, the relations and forces of production. It cannot be deduced from or reduced to it. All human activity is based on producing a natural and social environment; it is in this sense that the notion of the base is of fundamental importance. We have to eat and survive before we can and in order to enjoy leisure, entertainment, arts, and so on. The base is a precondition, a necessary, but not a sufficient condition for the superstructure. The superstructure is a complex, nonlinear creative reflection of the base, the base a complex, nonlinear creative reflection of the superstructure. This means that both levels are recursively linked and produce each other. Economic practices and structures trigger political and cultural processes. Cultural and political practices and structures trigger economic processes. The notion of creative reflection grasps the dialectic of chance and necessity/indetermination and determination that shapes the relationship of base and superstructure.

Applying this theoretical model of society to the phenomenon of Google surveillance allows distinguishing between personal, ecological, technological, economic, political and cultural data about users. These are dimensions of users' interests, i.e. of their cognition processes. Google's surveillance of users' cognition is organized along these different dimensions (see table 4). Furthermore, users make use of their knowledge in order to create user-generated content that also becomes the object of Google surveillance. 
Table 4 gives an overview of the various dimensions of Google surveillance: Google commodifies users' cognition, communication and co-operation by engaging in surveillance of these activities, creating data about them and selling these data to advertising clients. The cognition dimension features personal, ecological, technological, economic, political and cultural user data as well as user-generated content. Table 4 also lists examples for those Google services that conduct the surveillance of specific data.

Table 4. A typology of Google surveillance

\begin{tabular}{|c|c|c|c|}
\hline Surveillance Dimension & Surveillance Category & Surveillance Data & Example Applications \\
\hline Cognition & personal identity & $\begin{array}{l}\text { name, sex, place of child- } \\
\text { hood, country, current home } \\
\text { town, former home towns, } \\
\text { profession, company, former } \\
\text { companies, current school, } \\
\text { schools attended, interests, } \\
\text { self-description }\end{array}$ & Google Profiles, gMail \\
\hline Cognition & personal identity & Location & $\begin{array}{l}\text { Google Mobile applications } \\
\text { (Latitude, Goggles, Maps, } \\
\text { Mobile Search, gMail, Buzz, } \\
\text { etc), Google Chrome (opt-in), } \\
\text { Google Android (mobile OS) }\end{array}$ \\
\hline Cognition & personal identity & activities, schedule, meetings & Google Calendar \\
\hline \multirow[t]{2}{*}{ Cognition } & personal identity & $\begin{array}{l}\text { health data: hours slept, } \\
\text { weight, health problems, med- } \\
\text { ications, allergies, test results, } \\
\text { procedures, surgeries, immu- } \\
\text { nizations, insurances, copy of } \\
\text { health-related documents }\end{array}$ & \\
\hline & Google Health & & \\
\hline Cognition & $\begin{array}{l}\text { user-generated content } \\
\text { (UGC) }\end{array}$ & Videos & YouTube, Orkut \\
\hline Cognition & UGC & Images & Picasa, Orkut \\
\hline Cognition & UGC & Documents & Google Docs, Orkut \\
\hline Cognition & UGC & Postings & $\begin{array}{l}\text { Blogger, Blogspot, Orkut, } \\
\text { Knol, Moderator, Jaiku, Buzz }\end{array}$ \\
\hline Cognition & UGC & databases, tables & Google Fusion Tables \\
\hline Cognition & UGC & geo-tagged images & Google Panoramio \\
\hline Cognition & UGC & search-identified images & Google Goggles \\
\hline Cognition & UGC & reviews of places & Google Hotpot \\
\hline Cognition & UGC & document translations & Google Translator Toolkit \\
\hline Cognition & UGC & $\begin{array}{l}\text { Information about locally } \\
\text { stored documents }\end{array}$ & Google Desktop \\
\hline Cognition & economic data & consumer preferences & $\begin{array}{l}\text { Google Search, Shopping, } \\
\text { Images, Video, YouTube, } \\
\text { News, Books, Directory, } \\
\text { Blogs, Chrome+Web History } \\
\text { (visited websites), iGoogle, } \\
\text { Bookmarks (bookmarks of } \\
\text { favourite websites) }\end{array}$ \\
\hline Cognition & economic data & shopping behaviour & Google Checkout \\
\hline Cognition & economic data & $\begin{array}{l}\text { financial interests in compa- } \\
\text { nies }\end{array}$ & Google Finance \\
\hline
\end{tabular}




\begin{tabular}{|c|c|c|c|}
\hline Cognition & technological data & interests in technology & $\begin{array}{l}\text { Google Search, Shopping, } \\
\text { Images, Video, YouTube, } \\
\text { News, Books, Directory, } \\
\text { Blogs, Chrome+Web History } \\
\text { (visited websites), iGoogle, } \\
\text { Bookmarks (bookmarks of } \\
\text { favourite websites), Google } \\
\text { Earth, Maps }\end{array}$ \\
\hline Cognition & ecological data & $\begin{array}{l}\text { interests in nature and geog- } \\
\text { raphy }\end{array}$ & $\begin{array}{l}\text { Google Search, Shopping, } \\
\text { Images, Video, YouTube, } \\
\text { News, Books, Directory, } \\
\text { Blogs, Chrome+Web History } \\
\text { (visited websites), iGoogle, } \\
\text { Bookmarks (bookmarks of } \\
\text { favourite websites), Google } \\
\text { Earth, Maps }\end{array}$ \\
\hline Cognition & political data & political interests & $\begin{array}{l}\text { Google Search, Shopping, } \\
\text { Images, Video, YouTube, } \\
\text { News, Books, Directory, } \\
\text { Blogs, Chrome+Web History } \\
\text { (visited websites), iGoogle, } \\
\text { Bookmarks (bookmarks of } \\
\text { favourite websites) }\end{array}$ \\
\hline Cognition & cultural data & $\begin{array}{l}\text { cultural and entertainment } \\
\text { preferences }\end{array}$ & $\begin{array}{l}\text { Google Search, Shopping, } \\
\text { Images, Video, YouTube, } \\
\text { News, Books, Directory, } \\
\text { Blogs, Chrome+Web History } \\
\text { (visited websites), iGoogle, } \\
\text { Bookmarks (bookmarks of } \\
\text { favourite websites) }\end{array}$ \\
\hline Cognition & cultural data & reading preferences & Google Books \\
\hline Cognition & cultural data & academic interests & Google Scholar \\
\hline Cognition & cultural data & language interests & Google Translate \\
\hline Cognition & cultural data & travel interests & Google Maps, Earth \\
\hline Communication & & contacts, social network & $\begin{array}{l}\text { gMail, Google Groups, } \\
\text { YouTube, Google Documents, } \\
\text { Wave, Blogger/Blogspot, } \\
\text { Friend Connect, Jaiku, Buzz, } \\
\text { Orkut, Voice, Talk, Analytics }\end{array}$ \\
\hline Communication & & Communication content & $\begin{array}{l}\text { gMail, Google Groups, } \\
\text { YouTube, Blogger/Blogspot, } \\
\text { Jaiku, Buzz, Orkut, Wave, } \\
\text { Voice, Talk }\end{array}$ \\
\hline Co-operation & & $\begin{array}{l}\text { collaborative document } \\
\text { editing }\end{array}$ & Google Docs, Knol \\
\hline Co-operation & & Collective voting on topics & Google Moderator \\
\hline
\end{tabular}

Google is a legally registered company with its headquarters in Mountain View, California, United States. Its privacy policy is a typical expression of a self-regulatory privacy regime, in which businesses largely define themselves how they process personal user data. Privacy self-regulation by businesses is voluntary, therefore the number of organizations engaging in it tends to be very small (Bennett and Raab 2006:171): "Self-regulation will always suffer from the perception that it is more symbolic than real because those who are responsible for implementation are those who have a vested interest in the processing of personal data". The legal foundations of Google's economic surveillance of users are its terms of service and its privacy policies.

Google's general terms of services (http://www.google.com/accounts/TOS, version from April 16 2008) apply 
to all of its services. It thereby enables the economic surveillance of a diverse multitude of user data that is collected from various services and user activities for the purpose of targeted advertising: "Some of the Services are supported by advertising revenue and may display advertisements and promotions. These advertisements may be targeted to the content of information stored on the Services, queries made through the Services or other information".

In its privacy policy (http://www.google.com/intl/en/privacy/privacy-policy.html, version from October 3, 2010), Google specifies that the company "may collect the following types of information": personal registration information, cookies that store "user preferences", log information (requests, interactions with a service, IP address, browser type, browser language, date and time of requests, cookies that uniquely identify a user), user communications, location data, unique application number. Google says that it is using Cookies for "improving search results and ad selection", which is only a euphemism for saying that Google sells user data for advertising purposes. "Google also uses cookies in its advertising services to help advertisers and publishers serve and manage ads across the web and on Google services". To "serve and manage ads" means to exploit user data for economic purposes. The Google ad preferences manager (http://www.google.com/ads/preferences/) displays the user interests and preferences that are collected by the use of cookies and used for targeted advertising. So for example Google by its surveillance operations has correctly identified my personal interests in "Indie \& Alternative Music", "Rock Music", "Social Networks", "Social Sciences", "Dictionaries \& Encyclopaedias" and "Foreign Language Resources" and commodifies this information for its private business interests.

The combination of Google's terms of service and its privacy policy allows and legally enables the collection of a multitude of user data for the purpose of targeted advertising. These self-defined Google rules, in which users have no say and which are characteristic for privacy self-regulation, enable economic surveillance.

Google's privacy policy also specifies that "Google uses the DoubleClick advertising cookie on AdSense partner sites and certain Google services to help advertisers and publishers serve and manage ads across the web". Google uses DoubleClick, a commercial advertising server owned by Google since 2007 that collects and networks data about usage behaviour on various websites, sells this data, and helps providing targeted advertising - for networking the data it holds about its users with data about these users' browsing and usage behaviour on other web platforms. There is only an opt-out option from this form of networked economic surveillance. Google's privacy policy provides a link to this option. Opt-out options are always rather unlikely to be used because in many cases they are hidden inside of long privacy and usage terms and are therefore only really accessible to knowledgeable users. Many Internet corporations avoid opt-in advertising solutions because such mechanisms can drastically reduce the potential number of users participating in advertising. That Google helps advertisers to "serve and manage ads across the web" means that Google uses the DoubleClick server for collecting user behaviour data from all over the WWW and using this data for targeted advertising. Google's exploitation of users is not only limited to its own sites, its surveillance process is networked, spreads and tries to reach all over the WWW.

YouTube's privacy notice (http://www.youtube.com/t/privacy, version from December 8, 2010) says that "advertisers may serve ads based on interests and demographic categories associated with non-personally identifiable online activity, such as videos viewed, frequency of uploading or activity on other AdSense partner sites". This means that all user activities on YouTube and all activities of these users on WWW sites surveilled by Google or one of its subcompanies like DoubleClick can be used for targeted advertising.

Google services on mobile phones are regulated by the Google mobile privacy policy

http://www.google.com/mobile/privacy.html, version from December 14, 2010): The use of mobile Google services "may be sending us location information. This information may reveal your actual location". Also in the use of the service Google Buzz on a mobile device, "your location will be collected by Google" (Google Buzz privacy policy, http://www.google.com/buzz/help/intl/en/privacy.html, version from October 15, 2010). In combination with Google's general terms of service, these regulations enable location-based targeted advertising.

The analysis shows that Google makes use of privacy self-regulation for formulating privacy policies and terms of service that enable the large-scale economic surveillance of users for the purpose of capital accumulation. Advertising clients of Google, who use Google AdWords, are able to target ads for example by country, exact location of users and distance from a certain location, language users speak, the type of device used: (desktop/ laptop computer, mobile device (specifiable)), the mobile phone operator used (specifiable), gender, or age group (data source: http://adwords.google.com).

In December 2009, Google's CEO Eric Schmidt commented about online privacy: "If you have something that you do not want anyone to know, maybe you should not be doing it in the first place" (http://www.youtube.com/ watch?v=A6e7wfDHzew, accessed on February 15, 2011). Google's terms of service and privacy policies show that 
Google's economic aim is to accumulate profit by commodifying user data. Schmidt's statement is an indication that Google or at least its most important managers and shareholders do not value privacy very highly. It implies that Schmidt thinks that in the online world, all uploaded information, personal data and usage data should be commodified and the property of corporations so they can use if for economic ends.

\section{Conclusion: Is Google "Evil”?}

Google sees itself as "a company that does good things for the world" (Page and Brin, cited in: Jarvis 2009:99). One of its mottos is: "Don't be evil". "You can make money without doing evil" (http://www.google.com/ corporate/tenthings.html) is one of the slogans of Google's philosophy. This moral behaviour includes for Google that only "relevant" ads are displayed, that ads are not flashy, that ads are identified as "sponsored links". This paper has shown that Google permanently surveils the online behaviour of the users of Google services and thereby economically exploits them. In Google's moral universe, prosumer exploitation does not seem to be evil, but rather a moral virtue. Google thinks that advertising is evil when it displays irrelevant information, when it is flashy and if it is not recognizable as such. It ignores that the problem is that for organizing and targeting advertising, Google engages in the surveillance and exploitation of users and the commodification of personal data and usage behaviour data. Advertising is furthermore a mechanism that advances the monopolization of business, the manipulation of needs and the commercialization and commodification of culture and life. Advertising and exploitation are always "evil", therefore Google is just like all capitalist advertising companies "evil". In capitalism, evil is not a moral misconduct of individuals, who are blinded and could also act in more positive ways, exploitation is rather a structural and necessary feature of capital accumulation, which makes evil a generic feature of all forms of capitalism and of all capitalist organizations.

One could argue that Google provides a free service to users and that in return it should be allowed to access, store, analyze, and use personal data and Internet usage behaviour and that therefore this is a "fair exchange", not an "evil" relation of user expropriation and exploitation. But the problem is that the power relations between Google and its users are not symmetric. Targeted advertising on Google poses several threats:

- Ideological power threat: Online advertising presents certain realities as important to users and leaves out those realities that are non-corporate in character or that are produced by actors that do not have enough capital in order to purchase online advertisements. An online advertising monopoly therefore advances one-dimensional views of reality.

- Political power threat: In modern society, money is a form of influence on political power. The concentration of online advertising therefore gives Google huge political power.

- Control of labour standards and prices: An online advertising monopoly holds the power to set industry-wide labour standards and prices. This can pose disadvantages for workers and consumers.

- Economic centralization threat: An economic monopoly controls large market shares and thereby deprives other actors of economic opportunities.

- Surveillance threat: Targeted online advertising is based on the collection of vast amounts of personal user data and usage behaviour that is stored, analyzed, and passed on to advertising customers. Modern societies are stratified, which means that certain groups and individuals compete with others for the control of resources, consider others as their opponents, benefit from certain circumstances at the expense of others, etc. Therefore information about personal preferences and individual behaviour can cause harm to individuals if it gets into the hand of their opponents or others who might have an interest in harming them. Large-scale data gathering and surveillance in a society that is based on the principle of competition poses certain threats to the wellbeing of all citizens. Therefore special privacy protection mechanisms are needed. All large collections of data pose the threat of being accessed by individuals who want to harm others. If such collections are owned privately, then access to data might be sold because there is an economic interest in accumulating money. Humans, who live in modern societies, have an inherent interest in controlling, which personal data about them is stored and is available to whom because they are facing systemic threats of being harmed by others. Large collections of personal information pose under the given modern circumstances the threat that humans can be harmed because their foes, opponents, or rivals in private or professional life can potentially gain access to such data. Since $9 / 11$, there has been an extension and intensification of state surveillance that is based on the argument that security from terrorism is more important than privacy. But state surveillance is prone to failure, and the access of state institutions to large online collections about citizens (as for example enabled by the USA PATRIOT Act) not only poses the possibility for detecting terrorists, but also the threat that a large number of citizens is considered as potential criminals or terrorists without having committed any crimes and the threat that the state obtains a huge amount of information about the private lives of citizens that the latter consider worth protecting (as for example: political views, voting decisions, sexual preferences and relationships, friendship statuses). 
Many popular science accounts of Google are celebratory, whereas a lot of social science analyses point out the dangers of the company. One should go beyond one-sided assessments of Google and think dialectically: Google is at the same time the best and the worst that has ever happened on the Internet. Google is evil like the figure of Satan and good like the figure of God. It is the dialectical Good Evil. Google is part of the best Internet practices because it services can enhance and support the everyday life of humans. It can help them to find and organize information, to access public information, to communicate and co-operate with others. Google has the potential to greatly advance the cognition, communication and co-operation of humans in society. It is a manifestation of the productive and socializing forces of the Internet. The problem is not the technologies provided by Google, but the capitalist relations of production, in which these technologies are organized. The problem is that Google for providing its services necessarily has to exploit users and to engage in the surveillance and commodification of useroriented data.

Marx spoke in this context of the antagonism of the productive forces and the relations of production: "the material productive forces of society come into conflict with the existing relations of production. [...] From forms of development of the productive forces these relations turn into their fetters. Then begins an era of social revolution" (Marx 1859:263).

"In the development of productive forces there comes a stage when productive forces and means of intercourse are brought into being, which, under the existing relationships, only cause mischief, and are no longer productive but destructive forces (machinery and money); and connected with this a class is called forth, which has to bear all the burdens of society without enjoying its advantages, which, ousted from society, is forced into the most decided antagonism to all other classes; a class which forms the majority of all members of society" (Marx and Engels 1846:60).

The class relations framing Google, in which all Google users and web users are exploited by Google and in which the privacy of all of these individuals is necessarily violated by Google's business activities, are destructive forces - they destroy consumer privacy and human's interest in being protected from exploitation.

Google's cognitive, communicative and co-operative potentials point beyond capitalism. The social and cooperative dimension of the corporate web 2.0 anticipates and points towards "elements of the new society with which old collapsing bourgeois society itself is pregnant" (Marx 1871:335); new relations, which mature "within the framework of the old society" (Marx 1859:263); "new forces and new passions" that "spring up in the bosom of society, forces and passions which feel themselves to be fettered by that society" (Marx and Engels 1848:928); "antithetical forms", which are "concealed in society" and "mines to explode it" (Marx 1857/1858:159).

Google is a sorcerer of capitalism, it calls up a spell that questions capitalism itself:

"Modem bourgeois society with its relations of production, of exchange, and of property, a society that has conjured up such gigantic means of production and of exchange, is like the sorcerer who is no longer able to control the powers of the nether world whom he has called up by his spells" (Marx and Engels 1848:214).

At the level of the technological productive forces, we see that Google advances socialization, the co-operative and common character of the online-productive forces: Google tools are available for free, Google Documents allows the collaborative creation of documents; GMail, Blogger, and Buzz enable social networking and communication, YouTube supports sharing videos, Google Scholar and Google Books help better access worldwide academic knowledge, etc. These are all applications that can give great benefits to humans. But at the level of the relations of production, Google is a profit-oriented, advertising-financed moneymaking machine that turns users and their data into a commodity. And the result is large-scale surveillance and the immanent undermining of liberal democracy's intrinsic privacy value. Liberal democratic values thereby constitute their own limit and immanent critique. So on the level of the productive forces, Google and other web 2.0 platforms anticipate a commons-based public Internet from which all benefit, whereas the freedom (free service access) that it provides is now enabled by online surveillance and user commodification that threatens consumer privacy. Google is a prototypical example for the antagonisms between networked productive forces and capitalist relations of production of the information economy (Fuchs 2008).

"The conditions of bourgeois society are too narrow to comprise the wealth created by them" (Marx and Engels 1848:215). Google's immanent potentials that can enhance human life are limited by Google's class character - they cannot be realized within capitalism. The critical discussions that maintain that Google advances surveillance society, point towards Google's immanent limit as capitalist company.

Google is an antagonistic way of organizing human knowledge. Marx pointed out that knowledge and other 
productive forces constitute barriers to capital:

"The barrier to capital is that this entire development proceeds in a contradictory way, and that the working-out of the productive forces, of general wealth etc., knowledge etc., appears in such a way that [...] this antithetical form is itself fleeting, and produces the real conditions of its own suspension" (Marx 1857/1858:541f).

Google has created the real conditions of its own suspension.

It is a mistake to argue that Google should be dissolved or to say that alternatives to Google are needed or to say that its services are a danger to humanity. Rather, Google would loose its antagonistic character if it were expropriated and transformed into a public, non-profit, non-commercial organization that serves the common good. Google permanently expropriates and exploits Internet users by commodifying their content and user data. The best solution is the expropriation of the Google expropriator - the transformation of Google into a public search engine. Google stands at the same time for the universal and the particular interests on the Internet. It represents the idea of the advancement of an Internet that benefits humanity and the reality of the absolute exploitation of humanity for business purposes. Google is the universal exploiter and has created technologies that can advance a universal humanity if humans in an act of universal appropriation act as universal subject and free themselves and these technologies from exploitative class relations.

Karl Marx stressed that the globalization of production and circulation necessitates institutions that allow individuals to inform themselves on complex conditions. He said that "institutions emerge whereby each individual can acquire information about the activity of all others and attempt to adjust his own accordingly" and that these "interconnections" are enabled by "mails, telegraphs etc" (Marx 1857/58:161). Is this passage not the perfect description of the concept of the search engine? We can therefore say that Larry Page and Sergey Brin did not invent Google, but that rather the true inventor of the search engine and of Google was Karl Marx. But if Marx's thinking is crucial for the concept of the search engine, shouldn't we then think about the concept of a public search engine?

How could a public search engine look like? Google services could be run by non-profit organizations, for example universities (Maurer, Balke, Kappe, Kulathuramaiyer, Weber and Zaka 2007:74), and supported by public funding. A service like Google Books could then serve humanity by making the knowledge of all books freely available to all humans without drawing private profit from it. A public search engine does not require advertising funding if it is a non-profit endeavour. Thereby the exploitation and surveillance of users could be avoided and the privacy violation issues that are at the heart of Google could be avoided. Establishing a public Google were the dissolution of the private business of Google. This may only be possible by establishing a commons-based Internet in a commons-based society. For doing so, first steps in the class struggle for a just humanity and a just Internet are needed. These include for example the suggestion to require Google by law to make advertising an opt-in option and to surveil the surveillor by creating and supporting Google watchdog organizations that document the problems and antagonisms of Google. Google's 20\% policy is on the one hand pure capitalist ideology that wants to advance profit maximization. On the other hand, it makes sense that unions pressure Google to make these $20 \%$ of work time really autonomous from Google's control. If this could be established in a large company like Google, then a general demand for a reduction of labour time without wage decreases were easier to attain. Such a demand is a demand for the increase of the autonomy of labour from capital.

Another Google is possible, but this requires class struggle for and against Google in order to set free the humanistic (cognitive, communicative, co-operative) potentials of Google by overcoming its class relations.

\section{Acknowledgments}

The research presented in this paper was conducted in the project "Social Networking Sites in the Surveillance Society", funded by the Austrian Science Fund (FWF): project number P 22445-G17. Project co-ordination: Christian Fuchs 


\section{References}

Anderson, Chris. 2009. Free. The Future of a Radical Price. London: Random House.

Andrejevic, Mark. 2007. iSpy. Surveillance and Power in the Interactive Era. Lawrence, KS: University Press of Kansas.

Aljifri, Hassan and Diego Sánchez Navarro. 2004. "Search Engines and Privacy." Computers \& Security 23(5):379-388.

Auletta, Ken. 2010. Googled. The End of the World as We Know It. London: Virgin.

Baksik, Corinna. 2006. "Fair Use Exploitation? The Google Book Search Controversy." Libraries and the Academy 6(4):399-415.

Becker, Konrad. 2009. “The Power of Classification.” Pp. 163-172 in Deep Search. The Politics of Search beyond Google, edited by Konrad Becker and Felix Stalder. Innsbruck: StudienVerlag.

Bennett, Colin and Charles Raab. 2006. The Governance of Privacy. Cambridge, MA: MIT Press.

Bermejo, Fernando. 2009. "Audience Manufacture in Historical Perspective: From Broadcasting to Google." New Media \& Society 11(1/2):133-154.

Boltanski, Luc, and Éve Chiapello. 2006. The New Spirit of Capitalism. London: Verso.

Bourdieu, Pierre. 1986. “The (Three) Forms of Capital." Pp. 241-258 in Handbook of Theory and Research in the Sociology of Education, edited by John G. Richardson. New York: Greenwood Press.

Carr, Nicholas. 2008. "Is Google Making Us Stupid? What the Internet is Doing to Our Brains." The Atlantic July/August 2008.

Carr, Nicholas. 2009. The Big Switch. Rewiring the World, From Edison to Google. New York: W.W. Norton \& Company.

Darnton, Robert. 2009. "The Library in the Information Age." Pp. 32-44 in Deep Search. The Politics of Search Beyond Google, edited by Konrad Becker and Felix Stalder. Innsbruck: StudienVerlag.

Deleuze, Gilles. 1995. "Postscript on the Societies of Control." Pp. 177-182 in Negotiations. New York: Columbia University Press.

Diaz, Alejandro 2008. "Through the Google Goggles. Sociopolitical Bias in Search Engine Design." Pp. 11-34 in Web Search. Information Science and Knowledge Management, edited by Amanda Spink and Michael Zimmer. Berlin: Springer.

-----. 2008. Internet and Society. Social Theory in the Information Age. New York: Routledge.

-----. 2010a. "Labour in Informational Capitalism and on the Internet." The Information Society 26(3):179-196.
-----. 2010b. "Social Software and Web 2.0: Their Sociological Foundations and Implications." Pp. 764-789 in Handbook of Research on Web 2.0, 3.0, and X.0: Technologies, Business, and Social Applications, edited by San Murugesan, Volume II. Hershey, PA: IGI-Global.

-.--.. 2010c. "Theoretical Foundations of Defining the Participatory, Co-operative, Sustainable Information Society (PCSIS)." Information, Communication, and Society 13(1):23-47.

-.---. 2011. Foundations of Critical Media and Information Studies. New York: Routledge.

Giddens, Anthony. 1984. The Constitution of Society. Outline of the Theory of Structuration. Cambridge, UK: Polity Press.

Girard, Bernard. 2009. The Google Way. How One Company is Revolutionizing Management as we Know It. San Francisco, CA: No Starch Press.

Habermas, Jürgen. 1981. Theorie des kommunikativen Handelns. Frankfurt/Main: Suhrkamp.

Halavais, Alexander. 2009. Search Engine Society. Cambridge, UK: Polity Press.

Hardt, Michael and Antonio Negri. 2000. Empire. Cambridge, MA: Harvard University Press.

Haya, Glenn, Else Nygren and Wilhelm Widmark. 2007. "Metalib and Google Scholar. A User Study." Online Information Review 31(3):365-375.

Hindman, Matthew, Kostas Tsioutsiouliklis and Judy A. Johnson. 2003. " "Googlearchy". How a Few Heavily-Linked Sites Dominate Politics on the Web." Retrieved February 19, 2011 (www.cs.princeton.edu/ kt/mpsa03.pdf).

Hinman, Lawrence M. 2005. "Esse Est Indicato in Google: Ethical and Political Issues in Search Engines." International Review of Information Ethics 6:19-25.

Hoofnagle, Chris Jay. 2009. "Beyond Google and Evil. How Policy Makers, Journalists and Consumers Should Talk Differently about Google and Privacy." First Monday 14(4).

Introna, Lucas D. and Helen Nissenbaum. 2000. "Shaping the Web. Why the Politics of Search Engines Matters." The Information Society 16(3):169-185.

Jacsó, Péter. 2006. “Google Scholar: the Pros and Cons." Online Information Review 29(2):208-214.

Jakobsson, Peter and Fredrik Stiernstedt. 2010a. "Googleplex and Informational Culture." Pp. 113-137 in Media Houses. Architecture, Media and the Production of Centrality, edited by Staffan Ericson and Kristina Riegert. New York: Peter Lang.

----. 2010b. "Pirates of Silicon Valley. State of Exception and Dispossession in Web 2.0." First Monday 15(7). 
Jarvis, Jeff. 2009. What Would Google Do? New York: HarperCollins.

Jeanneney, Jean-Noël. 2007. Google and the Myth of Universal Knowledge. Chicago, IL: University of Chicago Press.

Jiang, Yuening. and Tsan-Kuo Chang. 2008. "State Requirement and Media Behavior. The Institutional Isomorphism of Google in China." Paper presented at the annual meeting of the International Communication Association, TBA, Montreal, Quebec, Canada, May 22, 2008. Retrieved February 19, 2011 (http://www.allacademic.com/meta/p231221_index.html).

Kang, Hyunjin. 2009. "You as a Commodity of Google. Examining Audience Commodification of Google.” Paper presented at the annual meeting of the International Communication Association, Marriott, Chicago, IL, May 20, 2009. Retrieved February 19, 2011 (http://www.allacademic. com/meta/p301019_index.html).

Kumar, Sangeet. 2010. "Google Earth and the Nation State. Sovereignty in the Age of New Media." Global Media and Communication 6(2):154-176.

Lee, Micky. 2010a. "A Political Economic Critique of Google Maps and Google Earth.” Information, Communication \& Society 13(6):909-928.

-----. 2010b. "Revisiting the 'Google in China' Question from a Political Economic Perspective." China Media Research 6(2):15-24.

-----. 2011. "Google ads and the blindspot debate." Media, Culture \& Society 33(3):433-447.

Lobet-Maris, Claire. 2009. "From Trust to Tracks. A Technology Assessment Perspective Revisited.” Pp. 73-84 in Deep Search. The Politics of Search Beyond Google, edited by Konrad Becker and Felix Stalder. Innsbruck: StudienVerlag.

Lovink, Geert. 2009. "Society of the Query. The Googlization Of Our Lives." Pp. 45-53 in Deep Search. The Politics of Search Beyond Google, edited by Konrad Becker and Felix Stalder. Innsbruck: StudienVerlag.

Marx, Karl. 1857/1858. Grundrisse. London: Penguin.

-.---. 1859. "A Contribution to the Critique of the Political Economy.” Pp. 257-417. In Marx Engels Collected Works (MECW), Volume 29. New York: International Publishers.

-----. 1867. Capital: Volume I. London: Penguin.

-.---. 1871. “The Civil War in France.” Pp. 307-359. In Marx Engels Collected Works (MECW), Volume 23. New York: International Publishers.

-----. 1894. Capital: Volume III. London: Penguin.

Marx, Karl and Friedrich Engels. 1846. The German Ideology. Amherst, NY: Prometheus Books.

-.-.-. 1848. "The Communist Manifesto." Pp. 203-243. In Economic and Philosophic Manuscripts of 1844. Amherst, NY: Prometheus Books.
Maurer, Hermann, Tilo Balke, Frank Kappe, Narayanan Kulathuramaiyer, Stefan Weber and Bilal Zaka. 2007. Report on Dangers and Opportunities Posed by Large Search Engines, Particularly Google. Retrieved February 19, 2011 (http:// www.google-watch.org/gpower.pdf).

Mayer, Katja. 2009. "On the Sociometry of Search Engines." Pp. 54-72. In Deep Search. The Politics of Search Beyond Google, edited by Konrad Becker and Felix Stalder. Innsbruck: StudienVerlag.

Menczer, Filippo, Santo Fortunato, Alessandro Flammini, Alessandro Vespignani. 2006. "Googlearchy or Googlocracy?” IEEE Spectrum. Retrieved February 19, 2011 (http://spectrum.ieee.org/telecom/internet/ googlearchy-or-googlocracy).

Mosco, Vincent. 2009. The Political Economy of Communication. 2 nd edition. London: SAGE.

Munir, Abu Bakar and Siti Hajar Mohd Yasin. 2008. "Google v EU. Do Disagreements Remain?” Intermedia 36(5):16-19.

Pan, Bing, Helene Hembrooke, Thorsten Joachims, Lori Lorigo, Geri Gay and Laura Granka. 2007. "In Google We Trust. Users' Decisions on Rank, Position, and Relevance." Journal of Computer-Mediated Communication 12(3):801-823.

Pasquinelli, Matteo. 2009. Google's PageRank Algorithm: A Diagram of Cognitive Capitalism and the Rentier of the Common Intellect. Pp. 152-162 in Deep search. The Politics of Search Beyond Google, edited by Konrad Becker and Felix Stalder. Innsbruck: StudienVerlag.

- - 2010. "The Ideology of Free Culture and the Grammar of Sabotage". Pp 285-304 in Education in the Creative Economy. Knowledge and Learning in the Age of Innovation, edited by Daniel Araya and Michael Peters. New York: Peter Lang.

Petersen, Søren Mørk. 2008. "Loser Generated Content. From Participation to Exploitation.” First Monday 13 (3).

Rieder, Bernhard. 2009. "Democratizing Search? From Critique to Society-Oriented Design.” Pp. 133-151 in Deep Search. The Politics of Search Beyond Google, ed. Konrad Becker and Felix Stalder. Innsbruck: StudienVerlag.

Rogers, Richard. 2009. “The Googlization Question. Towards the Inculpable Engine?” Pp. 173-184 in Deep Search. The Politics of Search Beyond Google, edited by Konrad Becker and Felix Stalder. Innsbruck: StudienVerlag.

Smythe, Dallas W. 1981/2006. "On the Audience Commodity and Its Work." Pp. 230-256 in Media and Cultural Studies, edited by Meenakshi Gigi Durham and Douglas Kellner. Malden, MA: Blackwell.

Stalder, Felix and Christine Mayer. 2009. "The Second Index. Search Engines, Personalization and Surveillance." Pp. 98-115 in Deep Search. The Politics of Search Beyond Google, edited by Konrad Becker and Felix Stalder. Innsbruck: StudienVerlag.

Stross, Randall. 2008. Planet Google. New York: Free Press. 
Tapscott, Don and Anthony D. Williams. 2006. Wikinomics. How Mass Collaboration Changes Everything. London: Penguin.

Tatli, Emin Islam. 2008. "Privacy in Danger. Let's Google Your Privacy." Pp. 51-59 in The Future of Identity in the Information Society, edited by Simone Fischer-Hübner, Penny Duquenoy, Albin Zuccato and Leonardo Martucci. Boston: Springer.

Tavani, Herman T. 2005. "Search Engines, Personal Information and the Problem of Privacy in Public." International Review of Information Ethics 6:39-45.

Toffler, Alvin. 1980. The Third Wave. New York, NY: Bantam.

Turow, Joseph. 2008. Niche Envy. Marketing Discrimination in the Digital Age. Cambridge, MA: MIT Press.

Vaidhyanathan, Siva. 2011. The Googlization of Everything (And Why We Should Worry). Berkeley, CA: University of California Press.

Van Couvering, Elizabeth. 2008. "The History of the Internet Search Engine. Navigational Media and the Traffic Commodity." Pp. 177-206 in Web Search. Information Science and Knowledge Management, edited by Amanda Spink and Michael Zimmer. Berlin: Springer.

Van Hoboken, Joris. 2009. "Search Engine Law and Freedom of Expression.” Pp. 85-97 in Deep Search. The Politics of Search Beyond Google, edited by Konrad Becker and Felix Stalder. Innsbruck: StudienVerlag.
Vise, David A. 2005. The Google Story. London: Macmillan.

Wasko, Janet and Mary Erickson. 2009. "The Political Economy of YouTube." Pp. 372-386 in The YouTube Reader. Stockholm: National Library of Sweden.

Weber, Stefan. 2009. Das Google-Copy-Paste-Syndrom. Hannover: Heise.

Zimmer, Michael. 2008a. "The Externalities of Search 2.0. The Emerging Privacy Threats When the Drive for the Perfect Search Engine Meets Web 2.0." First Monday 13 (3).

-----. 2008b. "The Gaze of the Perfect Search Engine: Google as an Infrastructure of Dataveillance." Pp. 77-99 in Web Search. Information Science and Knowledge Management, edited by Amanda Spink and Michael Zimmer. Berlin: Springer.

-----. 2010. "Web Search Studies. Multidisciplinary Perspectives on Web Search Engines." Pp. 507-521 in International Handbook of Internet Research, edited by Jeremy Hunsinger, Lisbeth Klastrup and Matthew Allen. Dordrecht: Springer.

Zook, Matthew A. and Mark Graham. 2007. "The Creative Reconstruction of the Internet. Google and the Privatization of Cyberspace and DigiPlace." Geoforum 38(6): 1322-1343. 